\title{
White Gold: Cassava as an Industrial Base
}

\author{
Nyerhovwo J. Tonukari1,2*, Theresa Ezedom1,2, Chinoye C. Enuma², Samson 0. Sakpa², \\ Oghenetega J. Avwioroko',2, Linda Eraga1,2, Enovwo Odiyoma ${ }^{2}$ \\ ${ }^{1}$ Department of Biochemistry, Faculty of Science, Delta State University, Abraka, Nigeria \\ ${ }^{2}$ African Research Laboratories, Otorho-Agbon, Ethiope-East LGA, Delta State, Nigeria \\ Email: ${ }^{*}$ tonukari@gmail.com
}

Received 15 February 2015; accepted 16 April 2015; published 20 April 2015

Copyright (C) 2015 by authors and Scientific Research Publishing Inc.

This work is licensed under the Creative Commons Attribution International License (CC BY). http://creativecommons.org/licenses/by/4.0/

\begin{abstract}
A great number of production sectors in Africa that make use of maize, rice and wheat starches have carried out several experiments on cassava (Manihot esculenta) flour and starch, and found them to be potentially valuable substitutes. The benefits ranged from being a human staple food, constituent of animal feeds, and raw material in food processing, textile, pharmaceutical, detergent, alcohol and plastic industries to production of confectioneries like bread, spaghetti and chinchin. The vast availability of this "white gold" in most African countries can be explored in order to fully maximize its potential as an industrial base for interested entrepreneurs.
\end{abstract}

\section{Keywords}

Cassava (Manihot esculenta), Flour, Starch, Diverse Applications, Industrial Base

\section{Introduction}

Cassava (Manihot esculenta) has a great potential to be used in Africa as an industrial base. This is due to the fact that cassava starch can perform most of the functions maize, rice and wheat starches are currently used for. Starch industrial application has evolved into a multibillion dollar business worldwide and as such, many more industries, mostly within Africa, have now developed multipurpose applications for starch especially cassava starch. Cassava starch, which is very mild in flavor and effluents generated from cassava starch processing units, are cheap feedstock and can be used as potential raw materials for industrial applications like ethanol production [1]. The demand for starch in Nigeria alone has recently been estimated to be around 67,100 tonnes per year and the amount of fresh cassava roots needed to produce that amount of starch is 350,000 tonnes [2]. High-grade cassava flour has the potential for use as an alternative to starch and other imported materials in a range of industries. This review will enlighten the scientific community and the public on the beneficial potentials of cassava as an industrial base.

${ }^{*}$ Corresponding author.

How to cite this paper: Tonukari, N.J., Ezedom, T., Enuma, C.C., Sakpa, S.O., Avwioroko, O.J., Eraga, L. and Odiyoma, E. (2015) White Gold: Cassava as an Industrial Base. American Journal of Plant Sciences, 6, 972-979. 


\section{Cassava-Based Animal Feeds Production}

Cassava (Figure 1) known as an energy source, is well suited for animal feeds, as demonstrated by its utilization in many countries. In 1994, about a quarter of the global cassava production was estimated to be used as an ingredient in pork, poultry, cattle, and fish feeds [3]. An industry that has livestock feed production as its subsidiary can utilize cassava in the production of its feed. Animal feed made of cassava can lead to increased number of feeds and also reduction of their cost in both commercial and subsistence production systems. A comparatively small amount of energy in feed extracts is caused by unavailability of cheap carbohydrate sources found in cassava. Using cassava as substitute of maize to some extent can be an achievable goal, if properly harnessed.

\section{Cassava Noodles, Cakes and Bread}

Instant noodle and spaghetti are carbohydrate-rich snacks made previously from wheat flour [4]. However, the use of cassava as a preferred substitute for wheat in their production has grossly increased over the last 3 decades due to alarming increase in the rate of consumption of instant noodle and spaghetti in Africa that awakened the need to source for other readily available and cheaper carbohydrate-rich substitutes or complements for wheat. The instant noodle and spaghetti industries produce millions of packs per year that are consumed by Africans and the rest of the world on daily basis. The cassava starch demands by these industries are in millions of tones, corresponding to millions of tones of fresh roots. Although statistics of their cassava starch demand is not available now, Indonesia has a cassava starch demand of 0.045 million tonnes corresponding to about 0.20 million tonnes of fresh roots [5].

\subsection{Cassava Cakes and Biscuits}

The production cost of cake and biscuit has been considerably reduced in recent times by mixing wheat flour and cassava starch in a specified manner. Cassava flours have now found important places in the Nigerian biscuit industry. Cassava is particularly used due to its good baking qualities and the fact that biscuit production is less gluten sensitive. According to Oyewole et al. [6], acceptable biscuits were produced by completely substituting wheat flour with cassava flour. However, cake and biscuit industries have good future prospects, and demand for cassava starch could increase as well.

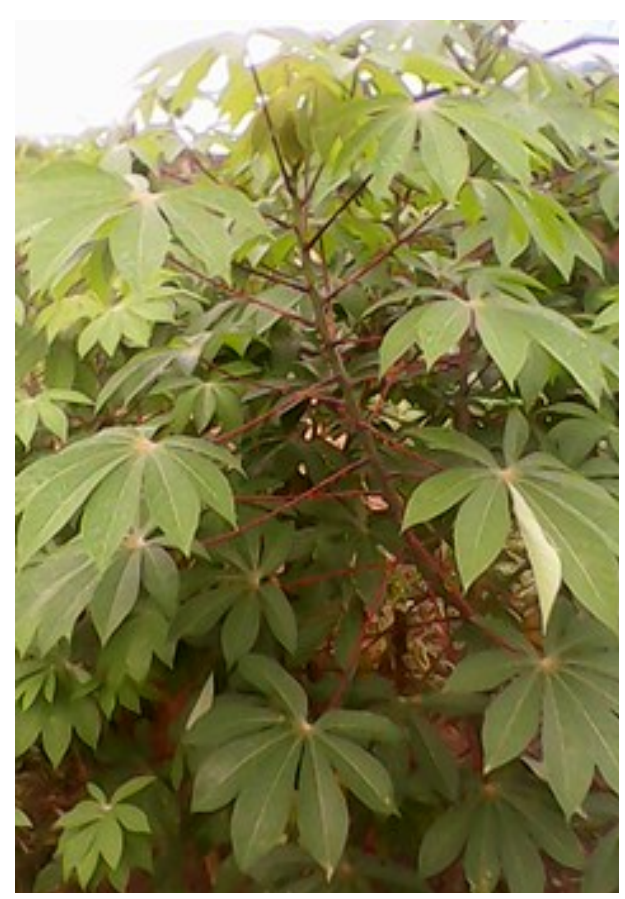

(a)

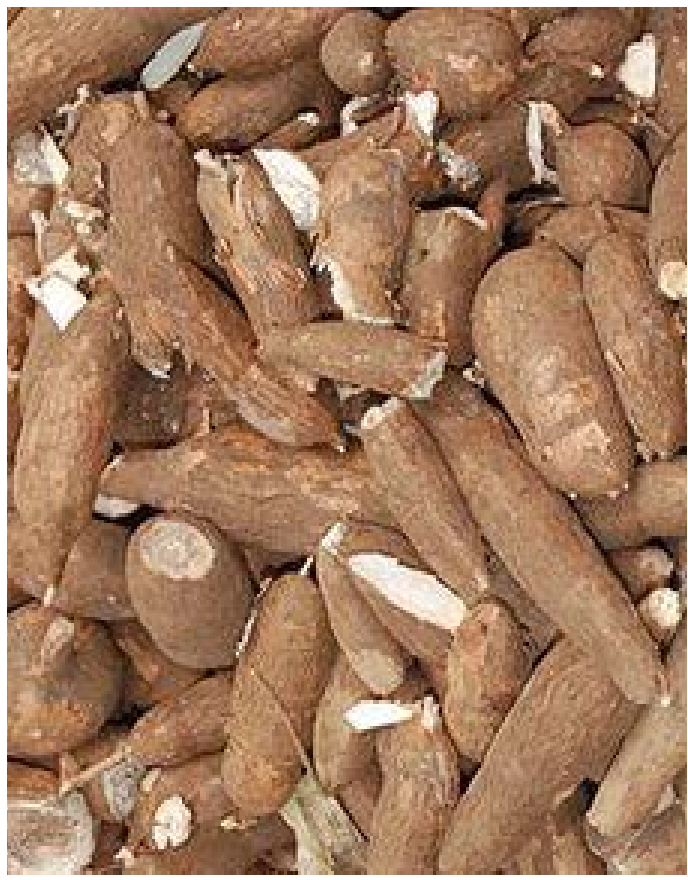

(b)

Figure 1. Cassava plant (a) and tubers (b). 


\subsection{Cassava Bread}

In many developing countries, bread consumption is continually expanding and there is increasing dependence on imported wheat. Cassava flour can be used as a substitute for wheat flour in many products, like bread. During the 1980s and 1990s, research bodies such as International Institute for Tropical Agriculture (IITA), Center for International Cooperation in Agronomic Research for Development (CIRAD) and The International Center for Tropical Agriculture (CIAT) did extensive researches on the utilization of cassava flour as a partial substitute for wheat in bread (up to 10\% - 15\%). Bokanga [7] showed that it is possible to increase the level of the nonwheat flour considerably without too great a change in the bread characteristics, provided certain bread improvers such as calcium stearyl lactylate are added or a relatively high percentage of fat and sugar is used.

\section{Cassava Starch in Textile Industries}

In the textile industries, modified starch (oxidized starch) is utilized in sizing and dyeing that make the finished fabrics look brighter, harder and with increased weight. Cassava starch is usually a preferred choice to other starches for sizing coarse yarn (wool) [8]. Textile printing or the impression of a design on fabrics requires a carrier for the dyes and pigments and modified cassava starch has found special use in these applications. Small quantity of cassava starch is also used as thickening agents in printing inks and for application of glossy finishes [8]. Cassava starch sticks in low temperature, which reduces the amount of energy used up. Compared to maize, it is totally sticky when boiled. Its size provides a clearer finish, makes yarn to be more pliable on the loom and produces qualities that last long. In Africa, particularly Ghana and Nigeria, many textile mills use homemade cassava flour to stiffen fabrics. Cassava flour, which is normally used in the production of lower quality fabrics such as those used for making uniforms and overalls, is selected on the basis of cheapness and availability [9]. Cassava starch is used to make bed sheets and table clothes to give them better quality, maintain their firmness and for their completion. Modern laundries regularly use soluble starch, wrapped with an appropriate propellant in air spray container for applying starch to clothes during steam ironing. Industries now use cassava starch because it has no issue in terms of quantity, quality and timely supply

\section{Cassava Starch in Pharmaceutical Industries}

The role of cassava in drug making processes cannot be under-estimated. In pharmaceutical industries, starch serves as a filler material and bonding agent for producing tablets in powder formulations [10]. Pharmaceutical manufacturers in Nigeria that produce cough syrups utilize crystalline and liquid glucose imported from Corn Products Corporation (CPC). Although, there is a high demand for sugar syrups, what is mostly required for its production is the availability of inexpensive and high quality starch found in cassava. This starch can be widely used in the making of tablets, capsules, and powder formulations [11]. In tablets, the starch is used for coating and dusting as well as binding the constituents of the tablet. In tablets and capsules, the starch also serves a special purpose, as it absorb moisture and swell after swallowing resulting in disintegration of the tablet and dispersal of the active ingredient [12].

\section{Cassava Starch in Detergent Industries}

In the manufacturing of soap and detergent, starch is used to get better recovery and to improve the shelf life of detergents [13]. Cassava starch is commonly used as fillers in producing soap; it is usually mixed with the particles of soap before milling. Cassava starch is not more advantageous than other materials in this area except for its relative abundance in Africa. Thus, there are special plans in African countries, particularly Nigeria to make cassava the power house for industrial and economic growth, if investors can only exploit it.

\section{Cassava Starch in Plastic Industries}

The increasing levels of pollution from durable polyurethane and polyethylene based films have provided the impetus for the development of partially and fully degradable plastic films and moldings [14]. Partially degradable films using surface-modified cassava starch have been developed and commercialized [15]. These films comprise of $40 \%$ cassava starch and $60 \%$ low-density polyethylene polymer, and they are partially broken down in the process. Exploitation of this technology in Africa would help in maximizing the potentials which lie dor- 
mant in cassava, especially in making it an industrial base. In Thailand, plastic films were made from $100 \%$ cassava starch using a process known as "annealing", which enables starch polymers to be converted into a flexible sheet [15]. This product is highly biodegradable, but its problem is related to high cost of production. In the rubber and foam industries, starch is used to get quality foam and color; also inclusive is cassava starch.

\section{Cassava Starch in the Production of Confectioneries}

Cassava starch can be converted to maltotriose and maltose as well as to other modified sugars and organic acids [16]. Starch is mostly used as an input for producing sugar syrups in a process known as controlled enzymatic hydrolysis, which involves the use of either acid or $\alpha$-amylase enzyme. Cutting the starch chain using acid will produce a mixture of dextrin maltose and glucose, and cassava starch is particularly suitable for this purpose. Simple methods produce several maltodextrins divisible products of starch, maltose and glucose. Starch from cassava can be used to make fructose syrups [17] and formulate gelatin capsules [18]. By controlling the processing greatly, cassava starch can almost be broken down to form glucose syrup. Enzymatic isomerization of glucose syrup is use for the preparation of high fructose syrup [5].

Nigeria has a considerably great food and beverage industry that depends on glucose syrup and crystalline sugar as inputs; however, they can be transformed to high fructose syrup in the future. Also, glucose syrup made from cassava starch can be utilized for the production of candy, soft drinks, traditional medicines and biscuits. Research has shown that the amylose content of cassava starch is lower than that of arrowroot, but the productivity of cassava roots is much higher than that of arrowroots [5]. Cassava starch is therefore suitable for domestic glucose and fructose syrup industries. These products (fructose and glucose syrups) can also serve as raw materials for large-scale factories. Enzymatic hydrolysis is essential for the production of glucose syrups from starch because specificity of enzymes allows the sugar syrups production with well-defined physical and chemical properties and also, milder enzymatic hydrolysis results in few side reactions and less browning [19]. Cassava starch can also be used to produce gums, pastes and other types of candies; it can be used to make moulds or to dust sweets for them not to stick together. Dextrose does not allow boiled sweets to crystallize and also reduces hydroscopicity in the finished product.

\section{Cassava Starch in the Production of Bioethanol}

The benefits of using cassava as a raw material for ethanol production are due to the fact that it can be planted on marginal lands where other agricultural crops such as sugarcane, rice, wheat and corn cannot be grown [20]. In addition, it can highly tolerate drought, as it survives during dry weather when soil moisture is low with high humidity. Unlike sugarcane, it needs soil with low quality since it performs well in poor soil than any other major food plant.

Several distilleries in Nigeria use cassava flour of high quality as a substrate for producing ethanol. Although, cassava flour is currently being used for alcohol production, yields are well below expectations with high levels of waste (sludge and unhydrolysed starch), blockages to heat exchangers, and increased hydrolysis times as well as the high cost of imported enzymes for saccharification [21]. But these constraints can be successfully surmounted with proper mechanization and government assistance. Industrial alcohol made from cassava starch can be used as feedstock to produce a large amount of organic chemicals like organic acids (citric acid and enzymes).

\section{Production of Adhesives from Cassava Starch}

The main raw material used in glue and adhesive industries is starch. Two things are very necessary for an adhesive to be effective. Other desired requirements are ease of application, reasonable setting time, resistance to moisture, aging, heat and fungal attack, non-staining and gap filling [22]. By virtue of its good adhesive qualities, cassava starch is an important raw material in adhesive industries.

Cassava starch has a strong film, clear paste, good water-holding properties, and stable viscosity. Adhesives made of cassava starch are used locally in corrugation box industry, paper conversion industry and liquid gum industry. They are made from by-products which are supposed to be wastes, which make them have very low cost advantage. Adhesives create a bonding between the adhesive and the product to be bonded. Locally made cassava starch has a viscous temperature of $62^{\circ} \mathrm{C}-68^{\circ} \mathrm{C}$, which makes it advantageous over maize. As a result, the use of caustic soda which changes the pasting temperature of maize from about $80^{\circ} \mathrm{C}$ to $65^{\circ} \mathrm{C}$ in the adhesive 
formulation is not required. The corrugated cardboard industry uses cassava dextrins to produce cartons, boxes and other packing materials. The layers of board are pasted together with a suspension of raw starch in a gelatinized solution. The board is pressed between hot rollers. This affects the gelatinization of the raw starch and leads to a very strong bonding. Cassava dextrins in aqueous solution re-dampen gums (used for stamps and envelopes) since they provide a high solids solution with clean machining properties.

These adhesives have applications in many industries. For example, cassava-based adhesives in oil industries are used to improve the viscosity of drilling muds in oil wells. Modified cassava starch (a mixture of clay) provides the bores with the right stickiness and water-holding capacity for drilling of oil wells or water wells. It is also used to close the walls of bore holes and prevents the loss of fluid. Cassava-based adhesives in cement industries are presently used as an additive in cement to improve the setting time.

\section{Cassava Flour in Plywood and Paperboard Industry}

In Nigeria, standard cassava flour can be produce and made available at a lower cost than wheat flour. This can pilot the way to further savings on unit cost of production. The plywood and paperboard industries simply make use of either high-grade cassava flour directly or adhesives which consist of mixtures of flour and one or more chemicals. The industries also make use of low quality cassava starch because they do not care about the cyanide content, microbiology, color, taste or odor of the flour. This makes low quality cassava starch to find application in this sector.

Cassava starch is used as an adhesive to make paper produced bright and strong. It is widely used as a tub size and beater size for producing paper. An important new application of cassava starch in paper industries is in the machine-coating of magazine paper, formerly done exclusively with caseins.

\section{Other Industrial Applications of Cassava and Its Waste Products}

Starch is also an essential natural resource used for manufacturing powder in the cosmetics industries, and cassava starch plays a very important role here. Activated carbons prepared from waste cassava peel are efficient as adsorbents for dyes and metal ions.

Wastes obtained from the harvesting and processing of cassava can be used for different purposes in various industries. A cassava starch production unit processing 100 tons of tubers per day has an output of 47 tons of fresh by-products, which may cause environmental problems when left in the surroundings or carelessly disposed of [23]. In Nigeria, cassava wastes are usually left to rot away or are burnt, leaving space for more waste to be gathered. The heaps emit carbon dioxide and produce a strong offensive smell. The use of cassava byproducts as feedstuffs or as an alternative substrate for biotechnological processes is a positive way to alleviate environmental issues [24]. These include cassava leaves, stems, peels and sievate. Cassava peels, leaves and stems are often left to rot away on farms and homesteads after harvesting the roots [25].

\subsection{Cassava Leaf}

Cassava leaves, a by-product of cassava root harvest is (depending on the varieties) rich in protein $(14 \%-40 \%$ dry matter), minerals, vitamins B1, B2, C and carotenes [26]. Cassava leaves contain a number of nutritionally active factors including linamarin, oxalic acid, phytic acid, tannic acid and trypsin and chymotrypsin inhibitors [27].

Cassava leaves as reasonably source of protein can reduce malnutrition in poor tropical and sub-tropical countries. Cassava leaves can be processed by alkaline fermentation in fermented vegetable called Ntoba mbodi which is consumed in Congo and Central Africa [28]. The main obstacle hampering the wide usage of cassava leaves as food is cyanogenic glucoside (contents of leaves), which depending on the variety, can be 6 times higher than the one seen in the roots. However, heat treatment is used to deliberately reduce the high level of cyanogenic glucosides present in the leaves [29].

\subsection{Cassava Peels}

Cassava peels form the bulk of residue from cassava root after post-harvest and processing. These peels could make up to about $10 \%$ of net weight of the roots [30]. Cassava peels serves as a good source of energy in ruminant feeding systems, serving either as the main basal diet or as a supplement. They constitute an important po- 
tential resource for animal feeds if properly processed by a bio-system [31]. Cassava peels have been employed as an important source of carbohydrate in livestock feeds for monogastrics in various parts of the world [32]. Because the detoxification of cyanogenic glucosides requires the presence of methionine, balanced feeds that include cassava peels must contain enough sulphur amino acids [33]. Cassava peel meal has also been consistently incorporated into the diets of pigs as alternative energy source [34].

Ofoefule and Uzodinma [30] have shown that biogas can be produced from blends of cassava peels with some animal wastes. Oparaku et al. [35] has also reported the production of methane from cassava peels while Obadina et al. [36] showed that cassava peel can be used as a substrate for microbial protein enrichment.

\subsection{Cassava Sievate}

Cassava sievate is also known as garri sievate. Cassava sievate is the by-product of the production of garri (also spelled gari), a popular West African food. Cassava sievate contains high amount of non-starch polysaccharides mostly of non-digestible carbohydrate such as cellulose hemicellulose, which have a high water holding capacity [37]. The sievate represents $15 \%-17 \%$ of the root in weight [38]. In Nigeria, cassava sieviate was used successfully in layers, causing only a minor decrease in egg production when $15 \%$ sievate was included in the diet [39]. Fermentation with Aspergillus slightly improved the rate of lay. Cassava sievate introduced as $18 \%-20 \%$ of the diet for growing rabbit (replacing the corresponding amount of maize grain) resulted in growth performance similar to, or slightly better than that obtained with the maize-based control diet [40].

\subsection{Cassava Stems}

Cassava stems have been over looked in starch and energy production. Cassava stem contains about 30\% starch (dry mass) mostly in the xylem than the phloem tissue. Up to $15 \%$ of the stem dry mass can be extracted using simple water based techniques, potentially leading to $87 \%$ increase in global cassava starch production. Cassava stems can be used for biofuel production without land use expansion [41]. Thus, in areas with large production of cassava stems potential exists for the exportation in the form of dehydrated stems. Large quantities of cassava stems could be chopped and mixed into silage for the feeding of cattle and pigs.

\section{Conclusions and Recommendations}

The importance of cassava in the agricultural economy of many tropical countries has grown remarkably in recent years and a great potential exists for cassava utilization as an industrial base in Africa. The food and starch industry in Africa should take advantage of the abundance of cassava production in the region to develop a local raw material base. Bakeries and confection industries should start to utilize cassava products, even at low levels of substitution for wheat flour, while they work out modalities for total substitution. The uniqueness of cassava in improving nutrition and bringing about national development in the food industry cannot be overemphasized. While other commodities such as corn, millet and soybean have been suggested and used as substitutes in the production of composite flours, the use of cassava has been shown to outweigh their benefits. Utilization of cassava would resolve the vicious cyclic effect associated with its production, increase stakeholders' income, create more jobs, solve some health problems, and reduce dependence on wheat importation. The improvement of market linkages also needs to be embarked upon.

Some of the products made from cassava require specialized secondary processing (for example, adhesive formulations) that cannot be done in the village. Hence, there is clearly a need for entrepreneurs who can bridge the necessary gaps to provide financial support for rural processors, and carry out secondary processing operations. Making cassava an industrial base by developing industries of cassava starch-derived products is a way to obtain a high added-value for cassava. Also, cassava could make a much more important contribution to national economies and provide a more stable base for industries, if cassava starch and cassava "wastes" could compete with other starches by improving the quality of its products and lowering the cost of production.

In summary, the vast availability of this "white gold" (cassava) in most African countries should be regarded as a natural plea for its exploration in order to fully maximize its potential as an industrial base for interested entrepreneurs.

\section{References}

[1] Verma, G.P., Nigam, P., Singh, D. and Chaudhary, K. (2000) Bioconversion of Starch to Ethanol in a Single-Step 
Process by Coculture of Amylolytic Yeasts and Saccharomyces cerevisiae 21. Bioresource Technology, 72, 261-266. http://dx.doi.org/10.1016/S0960-8524(99)00117-0

[2] Nang'ayo, F., Omanya, G., Bokanga, M., Odera, M., Muchiri, N., Ali, Z. and Werehire, P. (2005) A Strategy for Industrialisation of Cassava in Africa. Proceedings of a Small Group Meeting, African Agricultural Technology Foundation, Nairobi, 14-18 November 2005, 1-5.

[3] George, O.S. and Sese, B.T. (2012) The Effects of Whole Cassava Meal on Broiler Carcass Weight and the Optimal Inclusion Rate of Whole Cassava Meal in Broiler Production. Science and Engineering Research: Science Education Development Institute, 2, 184-189.

[4] Park, C.S. and Baik, B.-K. (2004) Relationship between Protein Characteristics and Instant Noodle Making Quality of Wheat Flour. Cereal Chemistry, 81, 159-164. http://dx.doi.org/10.1094/CCHEM.2004.81.2.159

[5] Richana, N., Makagiansar, H.Y., Suryani, A. and Irawadi, T.T. (2000) Pengaruh cara hidrolisis patiuntuk media pertumbuhan Bacillus sp. BMN14 penghasil biosurfaktan lipopeptida (Hydrolysis Methods of Starch for Culture Media of Bacillus sp. BMN14 Producing Biosurfactant Lipopeptide). Indonesian Journal of Microbiology, 5, 29-31.

[6] Oyewole, O.B., Sanni, L.O. and Ogunjobi, M.A. (1996) Production of Biscuits Using Cassava Flour. Nigerian Food Journal, 14, 25-30.

[7] Bokanga, M. (1998) Cassava in Africa: The Root of Development in the Twenty-First Century. Journal of Tropical Agriculture, 75, 89-92.

[8] Srinivas, T. (2007) Industrial Demand for Cassava Starch in India. Starch-Stärk, 59, 477-481. http://dx.doi.org/10.1002/star.200700657

[9] Braide, O.O. and Adetoro, S.A. (2013) Cassava Flour as a Resin Printing Paste for Textile Patterns, Abeokuta, Nigeria. Transnational Journal of Science and Technology, 3, 1-59.

[10] Singh, A.V. and Nath, L.K. (2012) Synthesis, characterization and compatibility study of acetylated starch with lamivudine. J. Therm. Anal. Calorimet. 108(1), 307-313. http://dx.doi.org/10.1007/s10973-011-1752-x

[11] Atichokudomchai, N. and Varavinit, S. (2003) Characterization and Utilization of Acid-Modified Cross-Linked Tapioca Starch in Pharmaceutical Tablets. Carbohydrate Polymers, 53, 263-270. http://dx.doi.org/10.1016/S0144-8617(03)00070-5

[12] Bos, C.E., Bolhuis, G.K., Van Doorne, H. and Lerk, C.F. (1987) Native Starch in Tablet Formulations: Properties on Compaction. Pharmaceutisch Weekblad, 9, 274-282. http://dx.doi.org/10.1007/BF01953630

[13] Tonukari, N.J. (2004) Cassava and the Future of Starch. Electronic Journal of Biotechnology, 7, 1-4. http://dx.doi.org/10.2225/vol7-issue1-fulltext-9

[14] Röper, H.H. and Koch, H. (1990) The Role of Starch in Biodegradable Thermoplastic Materials. Starch-Stärke, 42, 123-130. http://dx.doi.org/10.1002/star.19900420402

[15] Larotonda, F.D.S., Matsui, K.N., Soldi, V. and Laurindo, J.B. (2004) Biodegradable Films Made from Raw and Acetylated Cassava Starch. Brazilian Archives of Biology and Technology, 47, 477-484. http://dx.doi.org/10.1590/S1516-89132004000300019

[16] Tan, K.H., Ferguson, L.B. and Carlton, C. (1984) Conversion of Cassava Starch to Biomass, Carbohydrates, and Acids by Aspergillus niger. Journal of Applied Biochemistry, 6, 80-90.

[17] Vuilleumier, S. (1993) Worldwide Production of High Fructose Syrup and Crystalline Fructose. American Journal of Clinical Nutrition, 58, 733S-736S.

[18] Nduele, M., Ludwig, A. and Van Ooteghem, M. (1993) The Use of Cassava Starch in the Formulation of Gelatin Capsules. Journal de Pharmacie de Belgique, 48, 325-334.

[19] Lin, Y. and Tanaka, S. (2006) Ethanol Fermentation from Biomass Resources: Current State and Prospects. Applied Microbiology and Biotechnology, 69, 627-642. http://dx.doi.org/10.1007/s00253-005-0229-x

[20] Zhang, C., Han, W., Jing, X., Pu, G. and Wang, C. (2003) Life Cycle Economic Analysis of Fuel Ethanol Derived from Cassava in Southwest China. Renewable and Sustainable Energy Reviews, 7, 353-366. http://dx.doi.org/10.1016/S1364-0321(03)00057-1

[21] Vicentini, N.M., Cereda, M.P. and Câmara, F.L.A. (1999) Revestimentos de fécula de mandioca, perda de massa e alteração da cor de frutos de pimentão. Scientia Agricola, 56, 713-716. http://dx.doi.org/10.1590/S0103-90161999000300028

[22] Foschi, R.O. and Bonac, T. (1977) Load-Slip Characteristics for Connections with Common Nails. Wood Science, 9 , 118-123.

[23] Aro, S.O., Aletor, V.A., Tewe, O.O. and Agbede, J.O. (2010) Nutritional Potentials of Cassava Tuber Wastes: A Case Study of a Cassava Starch Processing Factory in Southwestern Nigeria. Livestock Research for Rural Development, 22, $1-11$. 
[24] Pandey, A., Soccol, C.R. and Mitchell, D. (2000) New Developments in Solid State Fermentation: Bioprocesses and Products. Process Biochemistry, 35, 1153-1169. http://dx.doi.org/10.1016/S0032-9592(00)00152-7

[25] Akinfala, E.O. and Tewe, O.O. (2004) Supplemental Effects of Feed Additives on the Utilization of Whole Cassava Plant by Growing Pigs in the Tropics. Livestock Research for Rural Development, 16, 1-10.

[26] Adewusi, S.R.A. and Bradbury, J.H. (1993) Carotenoids in Cassava: Comparison of Open Column and HPLC Methods of Analysis. Journal of the Science of Food and Agriculture, 62, 375-383. http://dx.doi.org/10.1002/jsfa.2740620411

[27] Ngudi, D.D., Kuo, Y.H. and Lambein, F. (2003) Cassava Cyanogens and Free Amino Acids in Raw and Cooked Leaves. Food and Chemical Toxicology, 41, 1193-1197. http://dx.doi.org/10.1016/S0278-6915(03)00111-X

[28] Mokemiabeka, S., Dhellot, J., Kobawila, S.C., Diakabana, P., Ntietie Loukombo, R.N., Nyanga-Koumou, A.G. and Louembe, D. (2011) Softening and Mineral Content of Cassava (Manihot esculenta Crantz) Leaves during the Fermentation to Produce Ntoba mbodi. Advance Journal of Food Science \& Technology, 3, 418-423.

[29] Fasuyi, A.O. (2005) Nutrient Composition and Processing Effects on Cassava Leaf (Manihot esculenta Crantz) Antinutrients. Pakistan Journal of Nutrition, 4, 37-42. http://dx.doi.org/10.3923/pjn.2005.37.42

[30] Ofoefule, A.U. and Uzodinma, E.O. (2009) Biogas Production from Blends of Cassava (Manihot utilissima) Peels with Some Animal Wastes. International Journal of Physical Sciences, 4, 398-402.

[31] Antai, S. and Mbongo, P. (1994) Utilization of Cassava Peels as Substrate for Crude Protein Formation. Plant Foods for Human Nutrition, 46, 345-351. http://dx.doi.org/10.1007/BF01088435

[32] Aro, S.O. (2008) Improvement in the Nutritive Quality of Cassava and Its By-Products through Microbial Fermentation. African Journal of Biotechnology, 7, 4789-4797.

[33] Okeke, G.C., Oji, U.I. and Uba, F.N. (1986) Maize Replacement Values of Cassava Peels in the Diet of Growing Rabbits. Beitrage zur Tropischen Landwirtschaft und Veterinarmedizin, 24, 221-226.

[34] Adesehinwa, A.O.K., Dafwang, I.I., Ogunmodede, B.K. and Tegbe, T.S.B. (1998) A Review of Utilization of Some Agro-Industrial By-Products in Pig Rations. Nigerian Journal of Agricultural Extension, 11, 50-64.

[35] Oparaku, N.F., Ofomatah, A.C. and Okoroigwe, E.C. (2013) Biodigestion of Cassava Peels Blended with Pig Dung for Methane Generation. African Journal of Biotechnology, 12, 5956-5961.

[36] Obadina, A., Oyewole, O., Abiola, S. and Sanni, L. (2006) Short Communication-Fungal Enrichment of Cassava Peels Proteins. African Journal of Biotechnology, 5, 302-304.

[37] Aderemi, F.A. and Nworgu, F.C. (2007) Nutritional Status of Cassava Peels and Root Sieviate Biodegraded with Aspergillus niger. American-Eurasian Journal of Agricultural \& Environmental Sciences, 2, 308-311.

[38] Nwokoro, S.O., Adegunloye, H.D. and Ikhinmwin, A.F. (2006) Nutritional Composition of Garri Sievates Collected from Some Locations in Southern Nigeria. Pakistan Journal of Nutrition, 4, 257-261.

[39] Aderemi, F.A. (2006) Microbial Degradation of Cassava Root Sieviate (CRS) and Its Utilization by Layers. Journal of Animal and Veterinary Advances, 5, 758-761.

[40] Ekwe, O.O., Osakwe, I.I. and Nweze, B.O. (2011) The Effect of Replacing Maize with Cassava "Sievate" Using Banana Leaves as Basal Forage in the Diet of Weaned Rabbit. Ozean Journal of Applied Sciences, 4, 51-58.

[41] Zhu, W., Lestander, T.A., Orberg, H., Wei, M., Hedman, B., Ren, J., Xie, G. and Xiong, S. (2013) Cassava Stems: A New Resource to Increase Food and Fuel Production. GCB Bioenergy, 7, 72-83. 